\title{
Chemistry of vinylidene complexes. XXIV. A new $\mu$-vinylidene complex containing RePt core, and platinum-bound carbonyl ligand. Spectroscopic, structural and electrochemical study
}

\author{
Victor V. Verpekin ${ }^{\mathrm{a}, 1}$, Alexander D. Vasiliev, ${ }^{\mathrm{b}, \mathrm{d}, \mathrm{d}}$, Alexander A. Kondrasenko ${ }^{\mathrm{a}}$, \\ Galina V. Burmakina ${ }^{\mathrm{a}, \mathrm{d}}$, Oleg S. Chudin ${ }^{\mathrm{a}}$, Nina I. Pavlenko ${ }^{\mathrm{a}}$, \\ Dmitry V. Zimonin ${ }^{a}$, Anatoly I. Rubaylo ${ }^{\text {a, c, d }}$ \\ ${ }^{a}$ Institute of Chemistry and Chemical Technology SB RAS, Federal Research Center \\ “Krasnoyarsk Science Center SB RAS”, Akademgorodok, 50-24, Krasnoyarsk 660036, Russia \\ ${ }^{b}$ Institute of Physics SB RAS, Federal Research Center "Krasnoyarsk Science Center SB \\ RAS”, Akademgorodok, 50-38, Krasnoyarsk 660036, Russia \\ ${ }^{c}$ Federal Research Center "Krasnoyarsk Science Center SB RAS", \\ Akademgorodok, 50, Krasnoyarsk 660036, Russia \\ ${ }^{d}$ Siberian Federal University, Svobodny Prospect, 79, Krasnoyarsk 660041, Russia
}

\begin{abstract}
The novel heterobinuclear $\mu$-vinylidene complex $\left[\mathrm{Cp}(\mathrm{CO})_{2} \mathrm{Re}(\mu-\mathrm{C}=\mathrm{CHPh}) \mathrm{Pt}\left(\mathrm{PPh}_{3}\right)(\mathrm{CO})\right]$ (1) was isolated from the reaction mixture of $\left[\mathrm{Cp}(\mathrm{CO})_{2} \mathrm{Re}(\mu-\mathrm{C}=\mathrm{CHPh}) \mathrm{Fe}(\mathrm{CO})_{4}\right]$ and $\mathrm{Pt}\left(\mathrm{PPh}_{3}\right)_{4}$ for the first time. Alternative high-yield synthetic approaches to 1 were developed including the reactions of $\left[\mathrm{Cp}(\mathrm{CO})_{2} \mathrm{Re}(\mu-\mathrm{C}=\mathrm{CHPh}) \mathrm{Pt}\left(\mathrm{PPh}_{3}\right)_{2}\right]$ (2) with $\mathrm{Co}_{2}(\mathrm{CO})_{8}$ and $\mathrm{Rh}(\mathrm{acac})(\mathrm{CO})_{2}$. The complex was characterized by IR and ${ }^{1} \mathrm{H},{ }^{13} \mathrm{C}$ and ${ }^{31} \mathrm{P}$ NMR spectroscopy, a molecular structure of 1 was determined by X-ray diffraction analysis. The electrochemical behavior of the new complex was studied by cyclic voltammetry at platinum or glassed carbon electrodes and by dc polarography at a dropping mercury electrode.
\end{abstract}

Keywords: Vinylidene complexes, heterometallic complexes, NMR, IR, X-ray diffraction, electrochemistry

\section{Introduction}

Organometallic compounds, in which two or more metals linked by hydrocarbon bridge, have attracted considerable attention due to their potential for application in synthesis, catalysis, and material science [1-7]. Understanding interactions between metals and their ligand environment in the heteronuclear organometallic complexes and clusters play an important role in the research of the processes that occur in homogeneous catalytic reactions and on metal surfaces [2,3,7]. The heterometallic vinylidene bridged complexes and clusters are one type of such compounds. They can be easily prepared by reaction of mononuclear vinylidene complexes of the type $L_{n} M=C=C R_{2}$ with unsaturated metal-containing fragments $[8,9]$. A wide variety of heterometallic vinylidene complexes [9-14] and clusters [8,9] containing $\mathrm{MM}^{\prime}, \mathrm{MM}_{2}^{\prime}$ and $\mathrm{MM}^{\prime} \mathrm{M}^{\prime \prime}$ cores were obtained by this method.

At the same time, in spite of the tens of known binuclear vinylidene complexes of the type $\mathrm{MM}$, the compounds containing the terminal $\mathrm{CO}$ ligand coordinated to the $\mathrm{Pt}$ atom are rare. Moreover, the X-ray structure of only [cis,cis- $\left.\mathrm{Pt}\left(\mathrm{C}_{6} \mathrm{~F}_{5}\right)_{2}(\mathrm{CO})(\mu-\mathrm{C}=\mathrm{CHPh}) \mathrm{Pt}\left(\mathrm{PPh}_{3}\right)_{2}\right]$ was determined [15]. This homometallic PtPt $\mu$-phenylvinylidene complex and its dimeric analog of the type $\left[\left\{\text { cis,cis- }(\mathrm{CO})\left(\mathrm{C}_{6} \mathrm{~F}_{5}\right)_{2} \mathrm{PtPt}\left(\mathrm{PPh}_{3}\right)_{2}\right\}_{2}\left\{\mu_{4}-1 \kappa \mathrm{C}^{\alpha}: 2 \kappa \mathrm{C}^{\alpha}: 3 \kappa \mathrm{C}^{\alpha \square}: 4 \kappa \mathrm{C}^{\alpha \square}-(1,4-\mathrm{C}=\mathrm{CH})_{2} \mathrm{C}_{6} \mathrm{H}_{4}\right\}\right] \quad$ were synthesized by reactions of $\left[\right.$ cis- $\left.\mathrm{PtR}_{2}(\mathrm{CO})(\mathrm{thf})\right]$ with corresponding acetylide and diyne complexes $[15,16]$. Reactions of bimetallic acyl complex $\left[(\mathrm{CO})_{3} \mathrm{Fe}\left\{\mu-\mathrm{Si}(\mathrm{OMe})_{2}(\mathrm{OMe})\right\}(\mu-\mathrm{dppm}) \mathrm{Pt}\{\mathrm{C}(\mathrm{O}) \mathrm{Me}\}\right]$ with acetylenes led to the series of vinylidene-bridged complexes $\left[(\mathrm{CO})_{3} \mathrm{Fe}(\mu-\mathrm{C}=\mathrm{CHR})(\mu-\right.$ dppm) $\mathrm{Pt}(\mathrm{CO})]\left(\mathrm{R}=\mathrm{Ph}, t\right.$-Bu, $n$-Bu) [17]. A related heterobimetallic complex $\left[(\mathrm{CO})_{4} \mathrm{~W}(\mu-\mathrm{dppm})(\mu-\right.$ $\left.\left.\mathrm{C}=\mathrm{CH}_{2}\right) \mathrm{Pt}(\mathrm{CO})\right]$ was prepared by deprotonation of the alkylidene bridged complex $\left[(\mathrm{CO})_{4} \mathrm{~W}(\mu-\right.$ dppm $)(\mu-\mathrm{CMe}) \mathrm{Pt}(\mathrm{CO})]\left[\mathrm{BF}_{4}\right]$ with $\mathrm{K}\left[\mathrm{BH}(\mathrm{CHMeEt})_{3}\right][18]$.

\footnotetext{
${ }^{1}$ Corresponding author. Tel.: +7 391205 1954; fax: +7 3912494108 (V.V. Verpekin).

E-mail address: vvv@icct.ru, vvv@icct.ru (V.V. Verpekin).
} 
Another route to the heterobimetallic complexes with the platinum-bound CO ligands is ligand exchange reactions $[19,20]$. Such ligand exchange can be performed in two main ways: by a treatment of the initial complex with gaseous carbon monoxide [20,21], or by a reaction of one with metal carbonyl compounds $[19,22,23]$. It should be noted that the carbon monoxide can initiate a cleavage of metal-metal bond and lead to decomposition of starting compound, for example, reactions of $\mu$-carbene complexes with $\mathrm{CO}$ lead to formation of triangular clusters containing $\mathrm{Pt}_{3}$ cores [24-26]. Reactions with metal carbonyl complexes can be accompanied by formation of trinuclear clusters $[22,27,28]$. However, in the case of reactions of the binuclear vinylidene complexes $\left[\mathrm{Cp}(\mathrm{CO})_{2} \mathrm{Mn}(\mu-\mathrm{C}=\mathrm{CHPh}) \mathrm{Pt}(\mathrm{L})_{2}\right]\left(\mathrm{L}=\mathrm{PPh}_{3}, \mathrm{P}\left(\mathrm{OPr}_{3}{ }^{\mathrm{i}}\right)\right)$ with $\mathrm{Co}_{2}(\mathrm{CO})_{8}$, the substitution of $\mathrm{L}$ by $\mathrm{CO}$ occured without decomposition to give tricarbonyl vinylidene species $\left[\mathrm{Cp}(\mathrm{CO})_{2} \mathrm{Mn}(\mu-\right.$ $\mathrm{C}=\mathrm{CHPh}) \mathrm{Pt}(\mathrm{L})(\mathrm{CO})]$ in high yields [23]. These results and potential of such complexes for further synthetic purposes encouraged us to develop methods for introduction of $\mathrm{CO}$ ligand in the $\mathrm{RePt}$ vinylidene complexes. Therefore, we report here the synthetic approaches to new mixed ligand tricarbonyl complex $\left[\mathrm{Cp}(\mathrm{CO})_{2} \operatorname{Re}(\mu-\mathrm{C}=\mathrm{CHPh}) \mathrm{Pt}\left(\mathrm{PPh}_{3}\right)(\mathrm{CO})\right]$, as well as its reactivity, molecular geometry, spectroscopic, and electrochemical properties. In this study we also try to evaluate an influence of CO substituent on the properties of the synthesized compound.

\section{Experimental}

\subsection{General considerations}

All operations and manipulations were carried out under an argon atmosphere. Reagent grate solvents were dried by the standard procedures, stored under argon, and freshly distilled prior to use. The course of reactions was monitored by TLC on Silufol plates and IR spectroscopy. Neutral alumina and silica gel were used for column chromatography. The X-ray, NMR, and IR data were obtained in the Krasnoyarsk Regional Centre of Research Equipment, Siberian Branch of the Russian Academy of Sciences. The IR spectra were recorded on the Tensor 27 spectrometer (Bruker, Germany). The ${ }^{1} \mathrm{H},{ }^{13} \mathrm{C}\left\{{ }^{1} \mathrm{H}\right\}$ and ${ }^{31} \mathrm{P}\left\{{ }^{1} \mathrm{H}\right\}$ NMR spectra were obtained using NMR spectrometer AVANCE III 600 DPX (Bruker, Germany). The X-ray data were obtained with the SMART APEX II diffractometer (Bruker AXS, Germany). The starting complexes of $\left[\mathrm{Cp}(\mathrm{CO})_{2} \mathrm{Re}=\mathrm{C}=\mathrm{CHPh}\right.$ ] [29], $\left[\mathrm{Pt}\left(\mathrm{PPh}_{3}\right)_{4}\right]$ [30], $\left[\mathrm{Fe}_{2}(\mathrm{CO})_{9}\right]$ [31] and [Rh(acac $\left.)(\mathrm{CO})_{2}\right]$ [32] were prepared according to the described methods. Preparation of $\left[\mathrm{Cp}(\mathrm{CO})_{2} \mathrm{Re}(\mu-\mathrm{C}=\mathrm{CHPh}) \mathrm{Pt}\left(\mathrm{PPh}_{3}\right)_{2}\right](2)$ and $\left[\mathrm{Cp}(\mathrm{CO})_{2} \operatorname{Re}(\mu-\mathrm{C}=\mathrm{CHPh}) \mathrm{Fe}(\mathrm{CO})_{4}\right]$ was described in [33] and [34]. All other reagents were obtained from commercial sources and used as received. Description of the reactions of complex 1 with $\mathrm{PPh}_{3}$, dppe and $\mathrm{Fe}_{2}(\mathrm{CO})_{9}$ are included in supplementary material.

\subsubsection{Reaction of $\left[\mathrm{Cp}(\mathrm{CO})_{2} \operatorname{Re}\left(\mu-1 \kappa C^{\alpha}: 2 \kappa C^{\alpha}-\mathrm{C}=\mathrm{CHPh}\right) \mathrm{Fe}(\mathrm{CO})_{4}\right]$ with $\mathrm{Pt}\left(\mathrm{PPh}_{3}\right)_{4}$}

$\mathrm{Pt}\left(\mathrm{PPh}_{3}\right)_{4} \quad(90 \mathrm{mg}, \quad 0.072 \mathrm{mmol})$ was added to a solution of $\left[\mathrm{Cp}(\mathrm{CO})_{2} \mathrm{Re}(\mu-\right.$ $\left.\mathrm{C}=\mathrm{CHPh}) \mathrm{Fe}(\mathrm{CO})_{4}\right](41 \mathrm{mg}, 0.071 \mathrm{mmol})$ in $10 \mathrm{~mL}$ of benzene and reaction mixture was stirred for 3 hours. The resulting solution was filtered through a pad of $\mathrm{SiO}_{2}(0.5 \times 2 \mathrm{~cm})$ and dried in vacuo. The residue was redissolved in hexane and chromatographed on $\mathrm{a} \mathrm{SiO}_{2}$ column $(8 \times 2 \mathrm{~cm})$. The column was successively eluted with hexane, hexane-benzene $(9: 1),(3: 2),(1: 1)$ mixtures and benzene.

The first light-pink eluate contained a mixture of $\mathrm{Fe}(\mathrm{CO})_{4} \mathrm{PPh}_{3}$ and $\mathrm{Fe}(\mathrm{CO})_{3}\left(\mathrm{PPh}_{3}\right)_{2}$, which were identified by IR spectra.

The second yellow band after evaporation of solvent and crystallization of a crude product

from benzene-hexane mixture (1:1) gave yellow microcrystals of $\left[\mathrm{Cp}(\mathrm{CO})_{2} \operatorname{Re}(\mu-\right.$ $\left.\mathrm{C}=\mathrm{CHPh}) \mathrm{Pt}\left(\mathrm{PPh}_{3}\right)(\mathrm{CO})\right]$ (1). Yield: $12 \mathrm{mg}, 19 \%$.

Anal. Found: C, 46.57; H, 2.89\%. Calc. for $\mathrm{C}_{34} \mathrm{H}_{26} \mathrm{O}_{3} \mathrm{PPtRe}$ (894.84): C, 46.64; H, $2.93 \%$.

IR $\left(\mathrm{CH}_{2} \mathrm{Cl}_{2}, \mathrm{~cm}^{-1}\right): 2030 \mathrm{~s}, 1941 \mathrm{~s}, 1878 \mathrm{~m}\left(v_{\mathrm{CO}}\right) ;\left(\mathrm{KBr}, \mathrm{cm}^{-1}\right): 2034 \mathrm{~s}, 1931 \mathrm{~s}, 1867 \mathrm{~s}\left(v_{\mathrm{CO}}\right)$.

${ }^{1} \mathrm{H}$ NMR $\left(\mathrm{CD}_{2} \mathrm{Cl}_{2},+25^{\circ} \mathrm{C}\right) \delta$, ppm $[J, \mathrm{~Hz}]: 5.37\left(\mathrm{~s}, 5 \mathrm{H}, \mathrm{C}_{5} \boldsymbol{H}_{5}\right) ; 7.04\left(\mathrm{~m}, 1 \mathrm{H}, \mathrm{H}_{\mathrm{m}}=\mathrm{C}^{2} \mathrm{HC}_{6} \boldsymbol{H}_{5}\right)$; $7.12\left(\mathrm{~m}, 2 \mathrm{H}, \mathrm{H}_{\mathrm{o}}=\mathrm{C}^{2} \mathrm{HC}_{6} \boldsymbol{H}_{5}\right) ; 7.20\left(\mathrm{~m}, 2 \mathrm{H}, \mathrm{H}_{\mathrm{m}}=\mathrm{C}^{2} \mathrm{HC}_{6} \boldsymbol{H}_{5}\right) ; 7.41\left(\mathrm{~s}, 1 \mathrm{H},=\mathrm{C}^{2} \boldsymbol{H P h}\right) ; 7.46-7.57(3 \mathrm{H}$, $\left.\mathrm{H}_{\mathrm{p}}+\mathrm{H}_{\mathrm{o}},-\mathrm{P}-\mathrm{C}_{6} \boldsymbol{H}_{5}\right) ; 7.62\left(\mathrm{~m}, 2 \mathrm{H}, \mathrm{H}_{\mathrm{m}},-\mathrm{P}-\mathrm{C}_{6} \boldsymbol{H}_{5}\right)$.

${ }^{13} \mathrm{C}\left\{{ }^{1} \mathrm{H}\right\} \operatorname{NMR}\left(\mathrm{CD}_{2} \mathrm{Cl}_{2},+25^{\circ} \mathrm{C}\right) \delta, \mathrm{ppm}[J, \mathrm{~Hz}]: 86.2\left(\mathrm{~s}, \mathrm{C}_{5} \mathrm{H}_{5}\right) ; 124.6\left(\mathrm{~s}, \mathrm{C}_{\mathrm{p}},=\mathrm{C}^{2} \mathrm{HC}_{6} \mathrm{H}_{5}\right)$; $126.4\left(\mathrm{~s}, \mathrm{C}_{\mathrm{m}},=\mathrm{C}^{2} \mathrm{HC}_{6} \mathrm{H}_{5}\right) ; 128.1\left(\mathrm{~s}, \mathrm{C}_{\mathrm{o}},=\mathrm{C}^{2} \mathrm{HC}_{6} \mathrm{H}_{5}\right) ; 128.3\left(\mathrm{~d},{ }^{3} J_{\mathrm{PC}}=10.6, \mathrm{C}_{\mathrm{m}},-\mathrm{PC}_{6} \mathrm{H}_{5}\right) ; 130.6\left(\mathrm{~s}, \mathrm{C}_{\mathrm{p}}\right.$, $\left.-\mathrm{PC}_{6} \mathrm{H}_{5}\right) ; 132.0\left(\mathrm{~d},{ }^{2} J_{\mathrm{PC}}=50.3,{ }^{2} J_{\mathrm{PtC}}=34.7, \mathrm{C}_{\mathrm{o}},-\mathrm{PC}_{6} \mathrm{H}_{5}\right) ; 134.1\left(\mathrm{~d}, J_{\mathrm{PC}}=12.5,{ }^{2} J_{\mathrm{PtC}}=22, \mathrm{C}_{\mathrm{ipso}}\right.$, - 
$\left.\mathrm{PC}_{6} \mathrm{H}_{5}\right) ; 142.3\left(\mathrm{~d},{ }^{3} J_{\mathrm{PC}}=6.5, \mathrm{C}_{\mathrm{ipso}},=\mathrm{C}^{2} \mathrm{HC}_{6} \mathrm{H}_{5}\right) ; 143.2\left(\mathrm{~d},{ }^{3} \boldsymbol{J}_{\mathrm{PtC}}=104,{ }^{4} J_{\mathrm{PC}}=5.5,=\boldsymbol{C}^{2} \mathrm{HPh}\right) ; 196.2(\mathrm{~s}$, $\left.{ }^{1} J_{\mathrm{PtC}}=1280, \mathrm{Pt}-\mathrm{CO}\right) ; 202.9$ (s, br., 2CO); $229.7\left(\mathrm{~d},{ }^{1} J_{\mathrm{PtC}}=855, \mu-\mathrm{C}^{1}\right)$.

${ }^{31} \mathrm{P}\left\{{ }^{1} \mathrm{H}\right\} \mathrm{NMR}\left(\mathrm{CD}_{2} \mathrm{Cl}_{2},+25^{\circ} \mathrm{C}\right) \delta$, ppm $[J, \mathrm{~Hz}]: 31.21\left(\mathrm{~d}, P^{1},{ }^{1} J_{\mathrm{PtP}}=4069\right)$.

${ }^{195} \mathrm{Pt}\left\{{ }^{1} \mathrm{H}\right\}$ NMR $\left(\mathrm{CD}_{2} \mathrm{Cl}_{2},+25^{\circ} \mathrm{C}\right) \delta$, ppm $[J, \mathrm{~Hz}]:-4764\left(\mathrm{~d},{ }^{1} J_{\mathrm{PtP}}=4080\right)$.

The third green-brown fraction after removal of solvent gave $32 \mathrm{mg}$ (43\%) of cluster $\left[\mathrm{CpReFePt}\left(\mu_{3}-\mathrm{C}=\mathrm{CHPh}\right)(\mathrm{CO})_{6} \mathrm{PPh}_{3}\right]$ that identified by IR spectra [27].

IR $\left(\mathrm{C}_{6} \mathrm{H}_{12}, \mathrm{~cm}^{-1}\right): 2054 \mathrm{~m}, 2039 \mathrm{~s}, 2012 \mathrm{~s}, 1972 \mathrm{~m}, 1959 \mathrm{~s}, 1950 \mathrm{~m}, 1936 \mathrm{~m}, 1923 \mathrm{w}, 1897 \mathrm{~m}$, $1873 \mathrm{w}\left(v_{\mathrm{CO}}\right) ;\left(\mathrm{KBr}, \mathrm{cm}^{-1}\right):\left(v_{\mathrm{CO}}\right) ;\left(\mathrm{KBr}, \mathrm{cm}^{-1}\right): 2039 \mathrm{~s}, 1997 \mathrm{~s}, 1961 \mathrm{sh}, 1952 \mathrm{~s}, 1936 \mathrm{~s}, 1913 \mathrm{sh}, 1870 \mathrm{~m}$ $\left(v_{\mathrm{CO}}\right)$.

The forth yellow fraction was eluted with benzene and after evaporation of solvent gave 25 mg $(31 \%)$ of $\left[\mathrm{Cp}(\mathrm{CO})_{2} \mathrm{Re}(\mu-\mathrm{C}=\mathrm{CHPh}) \mathrm{Pt}\left(\mathrm{PPh}_{3}\right)_{2}\right](2)$ identified by IR spectra [33].

IR $\left(\mathrm{CH}_{2} \mathrm{Cl}_{2}, \mathrm{~cm}^{-1}\right): 1933 \mathrm{~s}, 1858 \mathrm{~m}$, br $\left(v_{\mathrm{CO}}\right) ;\left(\mathrm{KBr}, \mathrm{cm}^{-1}\right): 1922 \mathrm{~s}, 1857 \mathrm{~m}\left(v_{\mathrm{CO}}\right)$.

\subsubsection{Reaction of $\left[\mathrm{Cp}(\mathrm{CO})_{2} \operatorname{Re}(\mu-\mathrm{C}=\mathrm{CHPh}) \operatorname{Pt}\left(\mathrm{PPh}_{3}\right)_{2}\right]$ with $\mathrm{Co}_{2}(\mathrm{CO})_{8}$}

$100 \mathrm{mg}(0.089 \mathrm{mmol})$ of $\mathbf{2}$ was dissolved in $10 \mathrm{~mL}$ of benzene in a $50 \mathrm{~mL}$ two-neck flask, then $31 \mathrm{mg}(0.091 \mathrm{mmol})$ of $\mathrm{Co}_{2}(\mathrm{CO})_{8}$ was added. The solution was allowed to stir at room temperature for 2 hours. The solvent was then removed in vacuo, the residue was redissolved in hexane-benzene (5:1) mixture and chromatographed on an alumina column $(7 \times 2 \mathrm{~cm})$. Two fractions were successively eluted with hexane, hexane-benzene (9:1) and (3:2) mixtures. The first brown fraction after evaporation of solvent gave $44 \mathrm{mg}(84 \%)$ of yellow-brown complex $\mathrm{Co}_{2}(\mathrm{CO})_{7}\left(\mathrm{PPh}_{3}\right)$ identified by IR spectra. Evaporation of solvent and crystallization of a crude product obtained from the second bright-yellow fraction gave $69 \mathrm{mg}(87 \%)$ of $\left[\mathrm{Cp}(\mathrm{CO})_{2} \operatorname{Re}(\mu-\right.$ $\left.\mathrm{C}=\mathrm{CHPh}) \mathrm{Pt}\left(\mathrm{PPh}_{3}\right)(\mathrm{CO})\right](\mathbf{1})$ as a yellow crystalline solid.

\subsubsection{Reaction of $\left[\mathrm{Cp}(\mathrm{CO})_{2} \operatorname{Re}(\mu-\mathrm{C}=\mathrm{CHPh}) \operatorname{Pt}\left(\mathrm{PPh}_{3}\right)_{2}\right]$ with $\operatorname{Rh}(\operatorname{acac})(\mathrm{CO})_{2}$}

The mixture of $50 \mathrm{mg}(0.044 \mathrm{mmol})$ of complex 2 and a $13 \mathrm{mg}(0.050 \mathrm{mmol})$ of $\mathrm{Rh}(\mathrm{acac})(\mathrm{CO})_{2}$ were heated at $70^{\circ} \mathrm{C}$ in $10 \mathrm{ml}$ of benzene for 2 hours. The resulting solution was evaporated, the residue was dissolved in hexane-benzene (5:1) mixture and chromatographed on an alumina column $(5 \times 2 \mathrm{~cm})$. Two fractions were successively eluted with hexane and hexanebenzene (3:2) mixture. The first yellow fraction after evaporation of solvent gave $22 \mathrm{mg}(90 \%)$ of yellow complex $\mathrm{Rh}(\mathrm{acac})(\mathrm{CO})\left(\mathrm{PPh}_{3}\right)$ identified by IR spectra. The second bright-yellow fraction after evaporation of solvent gave $32 \mathrm{mg}(81 \%)$ of yellow complex 1.

\subsection{X-ray diffraction studies of $\left[\mathrm{Cp}(\mathrm{CO})_{2} \operatorname{Re}(\mu-\mathrm{C}=\mathrm{CHPh}) \operatorname{Pt}\left(\mathrm{PPh}_{3}\right)(\mathrm{CO})\right](1)$}

Orange crystals of $\mu_{2}-\left[\right.$ (phenylethene-1,1-diyl-1:2 $\left.\left.\kappa^{2} \mathrm{C}\right)\right]$-tricarbonyl- $1 \kappa^{2} \mathrm{C}, 2 \kappa^{1} \mathrm{C}$ -

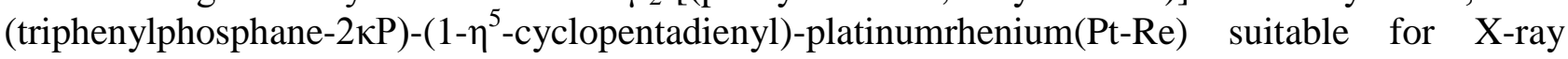
diffraction analysis were grown from a cyclohexane solution under argon atmosphere at $-20^{\circ} \mathrm{C}$.

$\mathrm{C}_{34} \mathrm{H}_{26} \mathrm{O}_{3}$ PPtRe-2( $\left.\mathrm{C}_{6} \mathrm{H}_{12}\right)$, monoclinic, $\mathrm{C} 2 / \mathrm{c}, \mathrm{a}=29.424(2), \mathrm{b}=13.3719(9), \mathrm{c}=24.937(2) \AA$, $\beta=119.2270(10)^{\circ}, V=8562.5(11) \AA^{3}, Z=8$. The experimental data were collected using fragment of a crystal, dimensions of $0.44 \times 0.28 \times 0.22 \mathrm{~mm}$, with a SMART Apex II diffractometer (Bruker AXS, $\mathrm{CCD}$ area detector, graphite monochromator, MoK $\alpha$ radiation, $\lambda=0.71073 \AA, 2 \theta \leq 52.74^{\circ}$ ); 34529 reflections were obtained at $296 \mathrm{~K}, 8753$ are unique. The experimental completeness is $99.8 \%$. Absorption corrections $\left(\mu_{\mathrm{Mo}}=6.163 \mathrm{~mm}^{-1}\right)$ have been applied using multiscan procedure [35], $\mathrm{R}_{\mathrm{int}}$ $=0.0844$. The structure was solved by direct methods and refined by full-matrix least squares on $\mathrm{F}^{2}$, using SHELXTL program [36]. Hydrogen atoms have been placed in calculated positions and taken into account in the final stages of refinement in the "riding model" approximation. All hexa- and pentagonal cyclic groups were refined in idealized form. The crystal cell contains solvent molecules, two of which are independent. One of them has the shape of a chair and the other is a slightly twisted boat. Refinement converged at a final R1 $=0.0522$ for reflections with $\mathrm{I}_{0}>2 \sigma_{\mathrm{I}}$ and 0.1144 for all 8753 data; $w R 2=0.148, \mathrm{GooF}=0.986,353$ refined parameters .

The supplementary crystallographic data for compound $\mathbf{1}$ have been deposited with the Cambridge Crystallographic Data Centre, CCDC No. 1431602 The data can be obtained free of charge via http://www.ccdc.cam.ac.uk or e-mail: deposit@ccdc.cam.ac.u. 


\subsection{Electrochemical study}

The electrochemical measurements were carried out in acetonitrile solutions with $0.1 \mathrm{M}$ $\left[\mathrm{Et}_{4} \mathrm{~N}\right]\left[\mathrm{BF}_{4}\right]$ as a supporting electrolyte. The cyclic voltammograms and dc polarograms were recorded on an IPC-Pro M potentiostat (Volta, Saint-Petersburg, Russia) with computer software using a three-electrode system. The working electrode was a stationary platinum electrode of $1 \mathrm{~mm}$ diameter or a stationary glassy carbon (GC) electrode of $3 \mathrm{~mm}$ diameter in a Teflon housings or a dropping mercury electrode (DME) with a positive margin drop $(\mathrm{m}=3.6 \mathrm{mg} / \mathrm{s}, \tau=0.23 \mathrm{~s})^{2}$. The reference electrode was $\mathrm{Ag} / 0.1 \mathrm{M} \mathrm{AgNO}_{3}$ in $\mathrm{MeCN}$. The auxiliary electrode was a platinum wire. The reference electrode and the auxiliary electrode were separated from the bulk solution in a glass tube filled with an electrolyte solution and fitted with a porous plug. The number of the electrons transferred in a particular redox process was estimated by comparison of the wave height observed with those of the one-electron ferrocene ${ }^{+/ 0}$ or $\mathrm{Cp}(\mathrm{CO})_{2} \mathrm{Re}=\mathrm{C}=\mathrm{CHPh}$ of the same concentration as well as through usual diagnostic electrochemical parameters.

\section{Results and discussion}

\subsection{Synthesis and reactivity of $\left[\mathrm{Cp}(\mathrm{CO})_{2} \operatorname{Re}(\mu-\mathrm{C}=\mathrm{CHPh}) \mathrm{Pt}\left(\mathrm{PPh}_{3}\right)(\mathrm{CO})\right]$}

As an extension of our study on synthesis and reactivity of heterometallic vinylidene complexes and clusters, we examined the possibility of synthesizing the known trinuclear cluster $\mathrm{CpReFePt}\left(\mu_{3}-\mathrm{C}=\mathrm{CHPh}\right)(\mathrm{CO})_{6}\left(\mathrm{PPh}_{3}\right)$ [27] in reaction of $\left[\mathrm{Cp}(\mathrm{CO})_{2} \operatorname{Re}(\mu-\mathrm{C}=\mathrm{CHPh}) \mathrm{Fe}(\mathrm{CO})_{4}\right]$ with $\mathrm{Pt}\left(\mathrm{PPh}_{3}\right)_{4}$. However, this reaction gave not only the expected ReFePt cluster but also an unexpected tricarbonyl heterobimetallic complex $\left[\mathrm{Cp}(\mathrm{CO})_{2} \mathrm{Re}(\mu-\mathrm{C}=\mathrm{CHPh}) \mathrm{Pt}\left(\mathrm{PPh}_{3}\right)(\mathrm{CO})\right]$ (1), which was isolated from the reaction mixture in $19 \%$ yield (Scheme 1). The complex $\left[\mathrm{Cp}(\mathrm{CO})_{2} \operatorname{Re}(\mu-\right.$ $\left.\mathrm{C}=\mathrm{CHPh}) \mathrm{Pt}\left(\mathrm{PPh}_{3}\right)(\mathrm{CO})\right]$ (1) is moderately air-stable red-orange crystalline solids, soluble in common organic solvents.
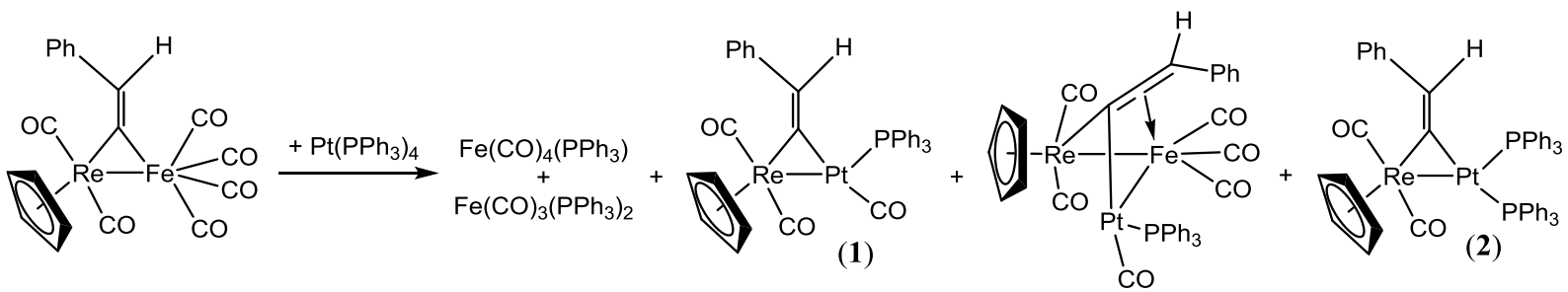

Scheme 1

In search of a more efficient and convenient route to the complex $\mathbf{1}$, we studied carbonylation reactions of $\left[\mathrm{Cp}(\mathrm{CO})_{2} \mathrm{Re}(\mu-\mathrm{C}=\mathrm{CHPh}) \mathrm{Pt}\left(\mathrm{PPh}_{3}\right)_{2}\right](2)$. Previously an analogous $\mathrm{MnPt}$ complex $\left[\mathrm{Cp}(\mathrm{CO})_{2} \mathrm{Mn}(\mu-\mathrm{C}=\mathrm{CHPh}) \mathrm{Pt}\left(\mathrm{PPh}_{3}\right)(\mathrm{CO})\right]$ (3) was prepared by the reaction of $\left[\mathrm{Cp}(\mathrm{CO})_{2} \mathrm{Mn}(\mu-\mathrm{C}=\mathrm{CHPh}) \mathrm{Pt}\left(\mathrm{PPh}_{3}\right)_{2}\right]$ and $\mathrm{Co}_{2}(\mathrm{CO})_{9}$ [23]. Following these strategy, we attempted to prepare complex 1. The treatment of 2 with $\mathrm{Co}_{2}(\mathrm{CO})_{9}(\mathrm{Scheme} 2)$ gave a red-orange solution from which complex 1 was isolated in high yield (87\%). The use of $\mathrm{Rh}(\mathrm{acac})(\mathrm{CO})_{2}$ instead of unstable $\mathrm{Co}_{2}(\mathrm{CO})_{8}$ also resulted in obtaining the desired complex, but to reach a quantitative yield of $\mathbf{1}$ the reaction must be performed in hot benzene for 2 hours.

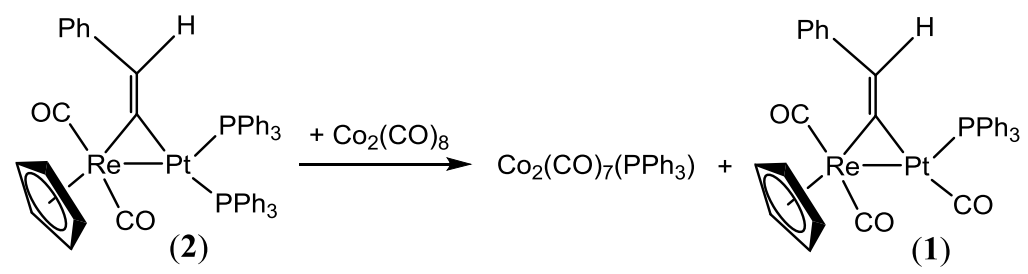

Scheme 2

\footnotetext{
${ }^{2}$ The application of different working electrodes offers an opportunity to study the oxidation and reduction properties of compounds in the extensive potential region. The measurement region of potentials in acetonitrile (vs. $\mathrm{Ag} / 0.1 \mathrm{M} \mathrm{AgNO}_{3}$ in $\mathrm{MeCN}$ ) is from 0.30 to $-3.20 \mathrm{~V}$ at DME, from 2.0 to $-2.2 \mathrm{~V}$, and from 2.0 to $-2.6 \mathrm{~V}$ at the Pt and GC electrodes, respectively.
} 
Unfortunately, our attempts to prepare the complex 1 by treating a dichloromethane solution of $\mathbf{2}$ with a gaseous carbon monoxide were unsuccessful. The traces of $\mathbf{1}$ in the reaction mixture were only detected by IR monitoring. Such results can be explained by the reverse reaction between 1 and a triphenylphosphane, in which the initial complex 2 regenerates. Indeed, the Pt-bound CO ligand of 1 can be readily substituted upon addition of such nucleophiles like $\mathrm{PPh}_{3}$ to give the complex 2 in high yield. Displacement of $\mathrm{CO}$ and $\mathrm{PPh}_{3}$ ligands occurs under reaction of 1 with 1,2bis(diphenylphosphino)ethane to yield the known RePt complex with dppe ligand at the Pt atom [33] (Scheme 3). The formation of both complexes in their reaction mixture was deduced from IR spectra in which a gradual decrease of the high frequency band at $2030 \mathrm{~cm}^{-1}$ and a low-frequency shift of the two $v(\mathrm{CO})$ bands of the Re-bound carbonyls are observed. The reaction of 1 with $\mathrm{Fe}_{2}(\mathrm{CO})_{9}$ results in the formation of the known cluster $\left[\mathrm{CpReFePt}\left(\mu_{3}-\mathrm{C}=\mathrm{CHPh}\right)(\mathrm{CO})_{6} \mathrm{PPh}_{3}\right]$ in $92 \%$ yield (Scheme 3).

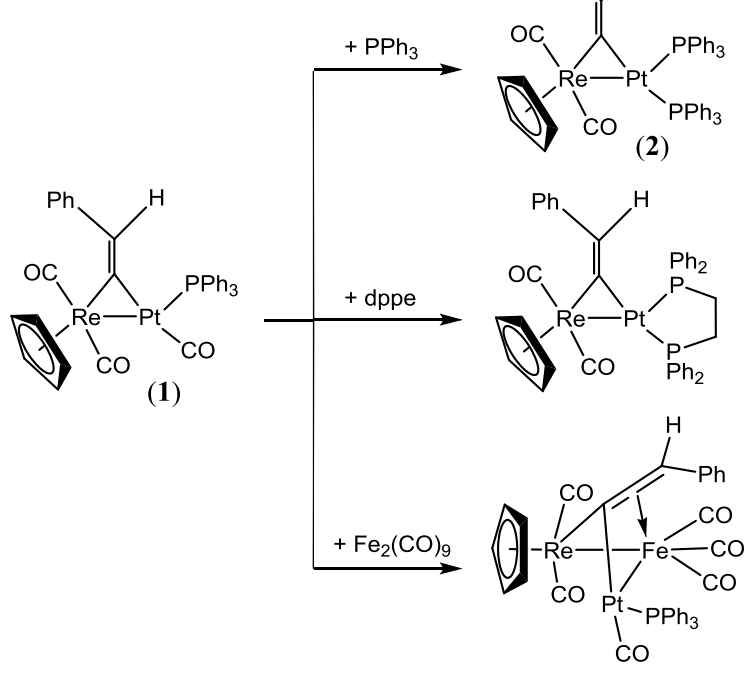

Scheme 3

\subsection{NMR and IR study}

The IR and the ${ }^{1} \mathrm{H},{ }^{13} \mathrm{C},{ }^{31} \mathrm{P}$ and ${ }^{195} \mathrm{Pt}$ NMR data for the complex 1 were obtained. The NMR signals were assigned on the basis of ${ }^{1} \mathrm{H},{ }^{13} \mathrm{C}\left\{{ }^{1} \mathrm{H}\right\}$ and ${ }^{1} \mathrm{H},{ }^{31} \mathrm{P}\left\{{ }^{1} \mathrm{H}\right\}$ correlations measured through HSQC and HMQC experiments, respectively. The structure of the complex can be deduced from the combined NMR and IR data, which are similar to those of previously described $\mu$-vinylidene complexes with $\operatorname{RePt}(\mathbf{2})$ and $\mathrm{MnPt}(\mathbf{3})$ cores (Table 1) $[9,14]$.

\section{Table 1.}

IR and NMR $(\delta$, ppm $[J, \mathrm{~Hz}])$ spectroscopic data for the $\left[\mathrm{Cp}(\mathrm{CO})_{2} \mathrm{M}(\mu-\mathrm{C}=\mathrm{CHPh}) \mathrm{Pt}\left(\mathrm{PPh}_{3}\right) \mathrm{L}\right]$ $\left(\mathrm{M}=\mathrm{Re}, \mathrm{L}=\mathrm{CO}(\mathbf{1}), \mathrm{L}=\mathrm{PPh}_{3}(\mathbf{2}) ; \mathrm{M}=\mathrm{Mn}, \mathrm{L}=\mathrm{CO}(\mathbf{3})\right)$. Chemical shifts of second isomer of complex $\mathbf{3}$ are marked with an asterisk $(*)$.

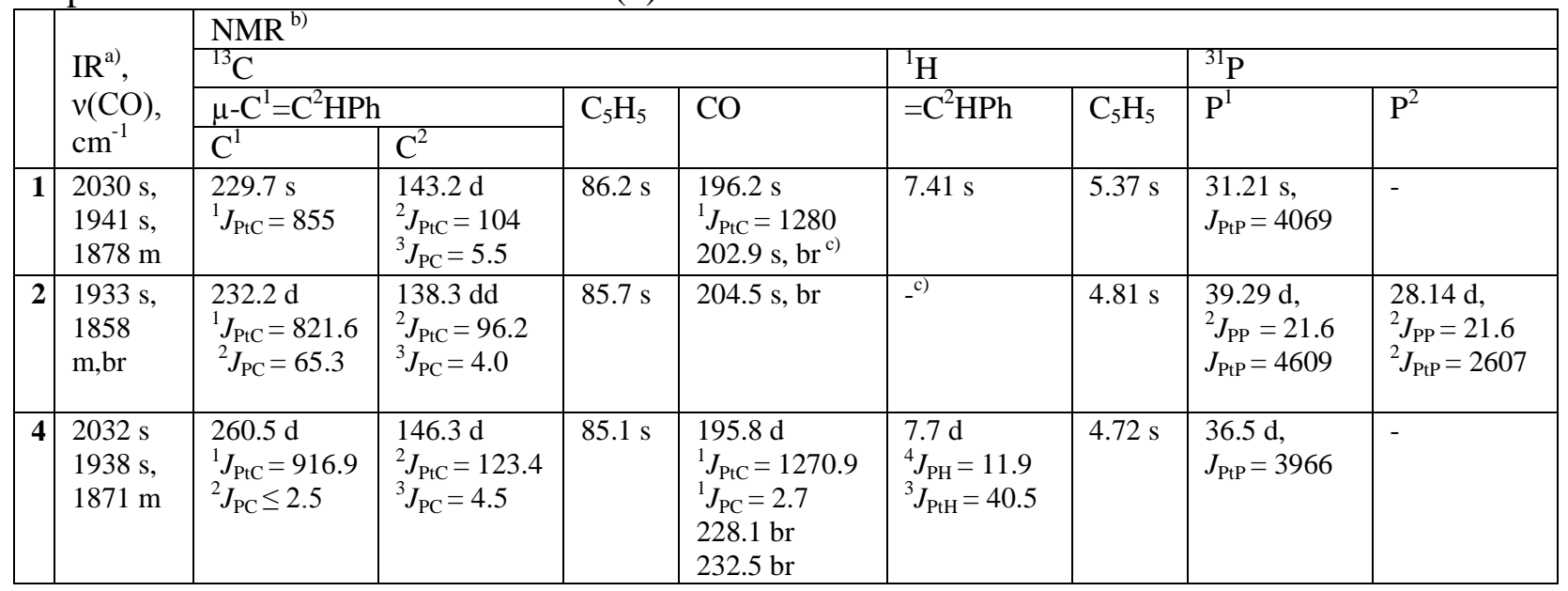


a) In $\mathrm{CH}_{2} \mathrm{Cl}_{2}$ solution;

b) In $\mathrm{CD}_{2} \mathrm{Cl}_{2}$ solution $(\mathbf{1 , 2}) \mathrm{CDCl}_{3}(4)$

c) $\mathrm{The}=\mathrm{C}^{2} \mathrm{H} \mathrm{Ph}$ signal is masked by the resonances of phenyl groups

The IR spectra of $\mathbf{1}$ in $\mathrm{CH}_{2} \mathrm{Cl}_{2}$ solution shows two $v(\mathrm{CO})$ bands $\left(1941,1878 \mathrm{~cm}^{-1}\right)$ that are attributed to the carbonyl groups at the Re atom. The Pt-bound $\mathrm{CO}$ in the spectrum of $\mathbf{1}$ gives rise to an addition absorption at $2030 \mathrm{~cm}^{-1}$.

In the ${ }^{1} \mathrm{H}$ NMR spectrum a singlet due to the vinylidene proton $=\mathrm{C}^{2} H$ is found at $\delta 7.41$. In the ${ }^{13} \mathrm{C}$ NMR spectrum of $\mathbf{1}$ a signal for the bridged $\mathrm{C}^{1}$ atom of the vinylidene is observed at $\delta 229.7$ with a $J_{\mathrm{PtC}}$ coupling of $855 \mathrm{~Hz}$, and this signal is upfield shifted by approximately $31 \mathrm{ppm}$ relative to that of the corresponding MnPt complex (3). A doublet at $\delta 143.2$ (with ${ }^{2} J_{\mathrm{PtC}}$ and ${ }^{3} J_{\mathrm{PC}}$ couplings of $104 \mathrm{~Hz}$ and $5.5 \mathrm{~Hz}$, respectively) arises from the $\mathrm{C}^{2}$ atom of vinylidene ligand. Similar chemical shifts of signals of the phenylvinylidene ligand in the ${ }^{1} \mathrm{H}$ and ${ }^{13} \mathrm{C}$ NMR spectra were earlier reported for the previously described $\mu$-vinylidene complexes $[17,18,33]$.

The ${ }^{13} \mathrm{C}$ NMR spectrum of 1 contains a broad resonance at $\delta 202.9$ that was assigned to the two Re-bound CO ligands. Such line broadness of the CO resonances can be explained by a site exchange of two carbonyl groups of the $\left[\mathrm{Cp}(\mathrm{CO})_{2} \mathrm{Re}\right]$ fragment and observed earlier [33,37-40]. The presence of one $\mathrm{CO}$ coordinated to the platinum atom in the ${ }^{13} \mathrm{C}$ NMR spectrum is indicated by a signal at $\delta 196.2$ with a $J_{\mathrm{PtC}}$ coupling of $1280 \mathrm{~Hz}$. Comparison of the ${ }^{13} \mathrm{C}$ NMR spectra parametres of 1 with those of the previously synthesized heterobinuclear vinylidene, carbyne and carbene complexes containing the Pt-bound CO groups revealed a dependence of the chemical shift of the platinum bound carbonyl group on its position toward a bridging hydrocarbon ligand. For example, in the ${ }^{13} \mathrm{C}$ NMR spectra of $\left[(\mathrm{CO}) \mathrm{Pt}(\mu-\mathrm{dppm})\left(\mu-\mathrm{C}(\mathrm{OMe}) \mathrm{C}_{6} \mathrm{H}_{4} \mathrm{Me}-4\right) \mathrm{W}(\mathrm{CO})_{4}\right][41]$, [(CO $)_{4} \mathrm{~W}(\mu-$ $\left.\mathrm{dppm})\left(\mu-\mathrm{C}=\mathrm{CH}_{2}\right) \mathrm{Pt}(\mathrm{CO})\right][18]$ and $\left[(\mathrm{CO})_{3} \mathrm{Fe}(\mu-\mathrm{C}=\mathrm{CHR})(\mu-\mathrm{dppm}) \mathrm{Pt}(\mathrm{CO})\right](\mathrm{R}=\mathrm{Ph}, t$-Bu $)$ [17] complexes in that the Pt-bound $\mathrm{CO}$ groups are in cis to the bridging ligand and trans to the second metal-containing fragment, the corresponding signals of the $\mathrm{CO}$ groups are observed in the ranges of $\delta 185-189 \mathrm{ppm}$. On the other hand, in the analogues manganese complex 3 and the $\mu$-carbyne complexes $\left[\mathrm{Cp}(\mathrm{CO})_{2} \mathrm{~W}(\mu-\mathrm{CR}) \mathrm{Pt}(\mathrm{CO})(\mathrm{L})\right]\left(\mathrm{R}=\mathrm{C}_{6} \mathrm{H}_{4} \mathrm{Me}-4, \mathrm{~L}=\mathrm{PMe}_{3}, \mathrm{PMe}_{2} \mathrm{Ph}, \mathrm{PPh}_{3} ; \mathrm{R}=\mathrm{C}_{6} \mathrm{H}_{3} \mathrm{Me}-\right.$ $\left.2,6, \mathrm{~L}=\mathrm{P}\left(\mathrm{Pr}^{1}\right)_{3}\right)[19,20]$, with the Pt-bound carbonyl located trance to vinylidene, the chemical shifts of the corresponding carbonyls are observed in the region of $\delta 195-199 \mathrm{ppm}$.

The position of $\mathrm{PPh}_{3}$ and CO ligands in $\mathbf{1}$ can also be unambiguously deduced from the ${ }^{31} \mathrm{P}$ NMR data. In the previous works [25,33], signals in the ${ }^{31} \mathrm{P}$ NMR spectra with a larger coupling constant are assigned to the phosphorus ligand trans to metal-containing fragment and the signals with a smaller $J_{\mathrm{PtP}}$ coupling are assigned to the ligand trans to the $\mu-\mathrm{C}=\mathrm{CHPh}$. In the ${ }^{31} \mathrm{P} \mathrm{NMR}$ spectrum of 1 the coupling constant $J_{\mathrm{PtP}}$ of a signal of the $\mathrm{PPh}_{3}$ ligand is comparable to those that were found for phosphorus-containing ligands that are trans to $\left[\mathrm{Cp}(\mathrm{CO})_{2} \mathrm{M}\right]$ fragments of the structurally well-defined vinylidene $\mathrm{MnPt}$ and RePt complexes [23,33,42]. So the trans position of $\mathrm{PPh}_{3}$ ligand to $\left[\mathrm{Cp}(\mathrm{CO})_{2} \mathrm{Re}\right.$ ] fragment in 1 is indicated by singlet with a $J_{\mathrm{PtP}}$ coupling of $4069 \mathrm{~Hz}$ at $\delta 31.2$ in the ${ }^{31} \mathrm{P}$ NMR spectrum (Table 1 ).

\subsection{Crystal structure}

The molecular structure of $\left[\mathrm{Cp}(\mathrm{CO})_{2} \mathrm{Re}(\mu-\mathrm{C}=\mathrm{CHPh}) \mathrm{Pt}\left(\mathrm{PPh}_{3}\right)(\mathrm{CO})\right](\mathbf{1})$ was solved on the base of X-ray diffractometry. Suitable crystals of 1 were grown from cyclohexane/hexane mixture. The view of the structure is shown in Fig.1. Selected bond distances and angles of $\mathbf{1}$ and the corresponding data for $\mathbf{2}$ are included in supplementary material for comparison purposes (Table S1). Crystal data and refinement parameters are shown in Table 2. 


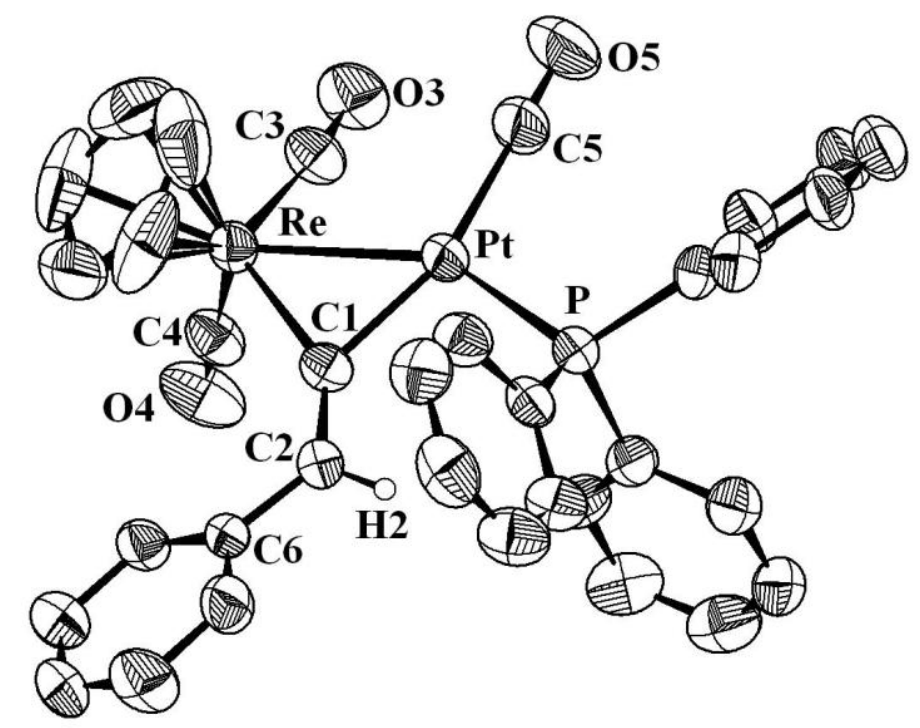

Fig. 1. Molecular structure of $\left[\mathrm{Cp}(\mathrm{CO})_{2} \mathrm{Re}(\mu-\mathrm{C}=\mathrm{CHPh}) \mathrm{Pt}\left(\mathrm{PPh}_{3}\right)(\mathrm{CO})\right](\mathbf{1})$. All hydrogen atoms except that of the phenylvinylidene ligand are omitted for clarity.

Table 2.

Crystal data and X-ray experimental details for complex 1

\begin{tabular}{|l|l|}
\hline Empirical formula & $\mathrm{C}_{34} \mathrm{H}_{26} \mathrm{O}_{3} \mathrm{PPtRe} \cdot 2\left(\mathrm{C}_{6} \mathrm{H}_{12}\right)$ \\
\hline Formula weight & 1063.12 \\
\hline Temperature/K & 296 \\
\hline Crystal system & Monoclinic \\
\hline Space group & $C 2 / c$ \\
\hline $\mathrm{a} / \AA$ & $29.424(2)$ \\
\hline $\mathrm{b} / \AA$ & $13.3719(9)$ \\
\hline $\mathrm{c} / \AA$ & $24.937(2)$ \\
\hline$\alpha /{ }^{\circ}$ & 90.00 \\
\hline$\beta /{ }^{\circ}$ & $119.227(10)$ \\
\hline$\gamma /{ }^{\circ}$ & 90.00 \\
\hline Volume/ $\AA^{3}$ & $8562.5(11)$ \\
\hline $\mathrm{Z}$ & 8 \\
\hline $\mathrm{d}_{\text {calc }} /\left(\mathrm{g} \cdot{ }^{-3}{ }^{-3}\right)$ & 1.649 \\
\hline$\mu / \mathrm{mm}^{-1}$ & 6.163 \\
\hline $\mathrm{F}(000)$ & 4144 \\
\hline Crystal size/mm & \\
\hline Radiation & $0.44 \times 0.28 \times 0.22$ \\
\hline $2 \Theta$ range for data collection $/{ }^{\circ}$ & 52.74 \\
\hline Reflections collected & 34529 \\
\hline Data/restraints/parameters & $8753 / 18 / 353$ \\
\hline Goodness-of-fit on $\mathrm{F}^{2}$ & 0.986 \\
\hline Final $\mathrm{R}_{1}[\mathrm{I}>=2 \sigma(\mathrm{I})]$ & 0.0522 \\
\hline Final $\mathrm{R}_{1}, w \mathrm{R}_{2}[$ all data $]$ & $0.1206,0.1480$ \\
\hline$\Delta \rho_{\text {min }} / \Delta \rho_{\text {max }}\left(\mathrm{e} / \AA^{3}\right)$ & $-0.90 / 1.01$ \\
\hline
\end{tabular}


The Re- and Pt-containing moieties of the complex are bridged by the $\mu$-vinylidene ligand to give a cycle RePtC1 with the Re-C1 and Pt-C1 distances of 2.065(10) and 2.024(10) $\AA$, respectively. The $\mathrm{C} 1=\mathrm{C} 2$ bond length is $1.330 \AA$. The $\mu-\mathrm{C}=\mathrm{CHPh}$ ligand is located in a plane of carbodimetallacycle; a dihedral angle between the ReC1Pt and C1C2C6 planes is 5.3(11) ${ }^{\circ}$. The short Re-Pt distance of 2.7187(6) $\AA$ indicates a metal-metal bond in the complex [43]. The bond angles Re-C1-Pt, C1-Pt-Re and Pt-Re-C1 are 83.3(4), 49.0(3) and 47.7(3) ${ }^{\circ}$, respectively.

The rhenium atom is coordinated by a $\eta^{5}$-cyclopentadienyl ligand and by two CO groups. The first carbonyl is terminal and forms an almost linear Re-C4-O4 angle of 177.6(10) ${ }^{\circ}$. The Re-C4 and C4-O4 bonds distances are 1.885(12) and 1.162(12) $\AA$, respectively. The Re-C3-O3 angle of the second carbonyl is $171.8(11)^{\circ}$. The length of Re-C3 and C3-O3 bonds are 1.908(12) and 1.171(13) $\AA$, and they are longer than those of the first carbonyl by 0.023 and $0.009 \AA$, respectively. These geometric parameters of the $\mathrm{C} 3 \mathrm{O} 3$ group might be interpreted as indicating a weak $\mathrm{Pt} \rightarrow \mathrm{C} 3 \mathrm{O} 3$ semibridging interaction. However, the Pt-C3 distance of 2.747(13) $\AA$ is too long to represent any bonding interactions between the adjacent platinum atom and $\mathrm{C} 3 \mathrm{O} 3$ group. This bond distance is longer than those found for the RePt complexes with a weak semibridging interaction [33]. Therefore, the $\mathrm{C} 3 \mathrm{O} 3$ ligand is just leaning toward the $\mathrm{Pt}$ atom and the rhenium-bound carbonyls should be considered as terminal.

The geometry around the platinum atom is a distorted square planar. The $\mathrm{PPh}_{3}$ and $\mathrm{CO}$ ligands form with RePt axis P1-Pt-Re and C5-Pt-Re angles of 146.63(7) and 113.0(4) , respectively. The Pt-P1 distance of 2.274(3) $\AA$ is typical, the same distances were found in previously described $\mu$-vinylidene complexes [33]. The platinum-bound $\mathrm{CO}$ ligand forms a linear Pt-C5-O5 angle of 178.2(15) ${ }^{\circ}$. The Pt-C5 and C5-O5 bond distances are 1.926(13) and 1.102(12) $\AA$, respectively. They are unusual and considerably differ from corresponding bond distances that were found in another heterobinuclear hydrocarbon bridged complexes containing the platinum-bounds carbonyl ligands, for example, $\left[\left(\mathrm{PBu}_{3}^{i}\right)(\mathrm{CO}) \mathrm{Pt}\left(\mu-\mathrm{H}_{2} \mathrm{CCPh}\right) \mathrm{Os}\left(\mathrm{SnPh}_{3}\right)(\mathrm{CO})_{4}\right](1.882(4)$ and 1.134(6) $\AA$ ) [44], $\left[\left(\mathrm{PPh}_{3}\right)(\mathrm{CO}) \mathrm{Pt}\left(\mu-\eta^{1}: \eta^{2}{ }_{\alpha, \beta}-\mathrm{C}(\mathrm{Ph})=\mathrm{C}=\mathrm{CH}_{2}\right) \mathrm{Ru}(\mathrm{CO}) \mathrm{Cp}\right](1.882(10)$ and 1.140(12) $\AA$ ) [22]. However, there are complexes in which the similar Pt-C and $\mathrm{C}-\mathrm{O}$ bond lengths are found, for example, a homobinuclear vinylidene complex [cis,cis- $\mathrm{Pt}\left(\mathrm{C}_{6} \mathrm{~F}_{5}\right)_{2}(\mathrm{CO})(\mu-\mathrm{C}=\mathrm{CHPh}) \mathrm{Pt}\left(\mathrm{PPh}_{3}\right)_{2}$ ] $(1.924(8)$ and $1.116(8) \AA) \quad[15]$ and a trinuclear carbyne cluster $\left[\mathrm{Pt}_{2} \mathrm{~W}\left(\mu_{3}-\mathrm{CC}_{6} \mathrm{H}_{4} \mathrm{Me}-\right.\right.$ 4) $(\mathrm{CO})_{4}\left(\mathrm{PMePh}_{2}\right)_{2}\left(\eta-\mathrm{C}_{5} \mathrm{H}_{5}\right)$ ] (1.83(5) and 1.11(7) $\AA$ ) [19]. Such elongation of Pt-C5 and shortening of $\mathrm{C} 5-\mathrm{O} 5$ bond length are probably a consequence of a strong electron-withdrawing ability of the phenylvinylidene ligand that is trans to $\mathrm{C} 5 \mathrm{O} 5$ group. The electron-withdrawing character of vinylidene and related hydrocarbon ligands has been also observed in other heterobimetallic complexes containing $\left[\mathrm{PtL}_{2}\right]\left(\mathrm{L}=\mathrm{PPh}_{3}(2), \mathrm{PMe}_{3}, \mathrm{PMe}_{2} \mathrm{Ph}, \mathrm{PMePh}_{2} ; \mathrm{L}_{2}=\mathrm{dppm}\right.$, dppe, dppp) fragments $[17,22,25,33,45]$. For example, the two Pt-P distances in $\mathbf{2}$ are unequal $(\mathrm{Pt}-\mathrm{P} 1=2.272(1)$ and Pt-P2 = 2.375(1) $\AA$ ), a longer Pt-P2 bond distance for the phosphorus atom is trans to the bridged vinylidene, and a short Pt-P1 bond distance is trans to the $\left[\mathrm{Cp}(\mathrm{CO})_{2} \mathrm{Re}\right]$ fragment [33]. Significantly, it is a $\mathrm{PPh}_{3}$ trans to vinylidene that undergoes substitution by $\mathrm{CO}$ in the complex 2; the other $\mathrm{PPh}_{3}$ ligand trans to $\left[\mathrm{Cp}(\mathrm{CO})_{2} \mathrm{Re}\right]$ fragment remains bound to the $\mathrm{Pt}$ atom after carbonylation.

The presence of $\mathrm{CO}$ at the Pt was found to slightly influence the geometrical parameters of the carbodimetallacycle and the vinylidene ligand of $\mathbf{1}$ in comparison with the RePt complexes with chilate diphosphine and two $\mathrm{PPh}_{3}$ (2) ligands. Comparison of the structure features of $\mathbf{2}$ and $\mathbf{1}$ revealed that on passing from 2 to 1 the Re-C1 and $\mathrm{C} 1=\mathrm{C} 2$ bond distances decrease from 2.083(5) and 1.351(6) $\AA$ to $2.065(10)$ and 1.330(12) $\AA$, respectively, whereas the Pt-C1 bond length increases from 2.008(4) to 2.024(10) $\AA$. The RePt bond distance in 2 is by $0.017 \AA$ shorter than that in 1 . The changes in the bond angles Re-C1-Pt, C1-Pt-Re and Pt-Re-C1 of the carbodimetallacycle are minor. Despite some differences in geometrical parameters between $\mathbf{2}$ and $\mathbf{1}$, an overall geometry of complex $\mathbf{1}$ is therefore close to that of the $\mu$-vinylidene RePt complexes described previously [33].

\subsection{Electrochemistry}

The redox properties of complex 1 were studied by cyclic voltammetry $(\mathrm{CV})$ at platinum or glassy carbon (GC) electrodes and by dc polarography at a dropping mercury electrode (DME) in 
acetonitrile solutions. Potentials are given versus $\mathrm{Ag} / 0.1 \mathrm{M} \mathrm{AgNO}_{3}$ in $\mathrm{MeCN}$ (they can be converted to $V$ versus $S C E$ by adding $0.337 \mathrm{~V})$.

The complex $\left[\mathrm{Cp}(\mathrm{CO})_{2} \operatorname{Re}(\mu-\mathrm{C}=\mathrm{CHPh}) \mathrm{Pt}\left(\mathrm{PPh}_{3}\right)(\mathrm{CO})\right](\mathbf{1})$ exhibits at the GC-electrode two one-electron oxidation stages $\left(E_{1 / 2}=0.18,1.02 \mathrm{~V}\right)$ and one-electron reduction stage $\left(E_{1 / 2}=-2.32 \mathrm{~V}\right)$ (Fig. 2 - solid line). At the Pt-electrode the $\mathrm{CV}$ shows only two one-electron oxidation stages at $E_{1 / 2}$ $=0.17$ and 1.07 V. First oxidation waves at the Pt and GC-electrodes (Fig. 2 - dotted line, peaks $\mathrm{A}_{1}$ and $\left.A_{1} \square\right)$ are electrochemically quasi-reversible ${ }^{3}$. The reduction of $\mathbf{1}$ at the GC-electrode is electrochemically quasi-reversible ${ }^{4}$ (Fig.2, peaks $\mathrm{A}_{3}, \mathrm{~A}_{3}{ }^{\prime}$ ). At the DM electrode 1 shows three reduction waves at $E_{1 / 2}=-2.33,-3.00$ and $-3.10 \mathrm{~V}$, respectively.

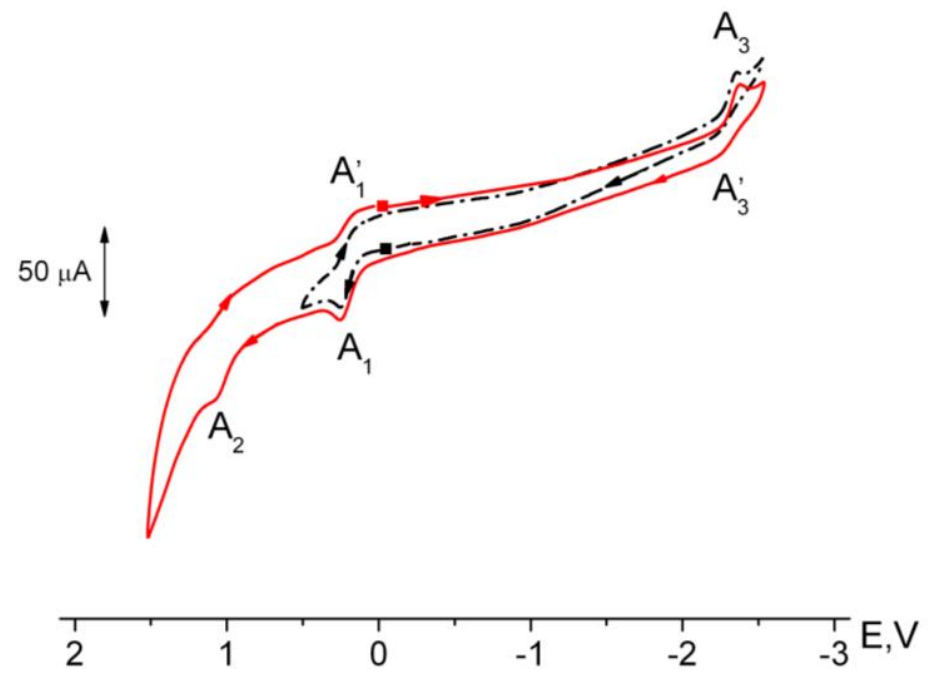

Fig. 2. The cyclic voltammograms of 1 at GC-electrode in $\mathrm{MeCN}\left(0.1 \mathrm{M} \mathrm{Et}_{4} \mathrm{NBF}_{4}, \mathrm{C}=2\right.$ $\mathrm{mM}$, scan rate $25 \mathrm{mV} \mathrm{s}^{-1}$, potentials vs. $\mathrm{Ag} / 0.1 \mathrm{M} \mathrm{AgNO}_{3}$ in $\mathrm{MeCN}$ ) (solid line - the initial negative potential sweep, dotted line - the initial positive potential sweep).

In our previous work [46], more negative oxidation $\left(E_{1 / 2}=-0.07,0.26,0.33 \mathrm{~V}\right.$ at the $\mathrm{Pt}$ electrode) and reduction $\left(E_{1 / 2}=-2.60,-2.80\right.$ и $-3.00 \mathrm{~V}$ at the DME) potentials are found for the complex $\left[\mathrm{Cp}(\mathrm{CO})_{2} \mathrm{Re}(\mu-\mathrm{C}=\mathrm{CHPh}) \mathrm{Pt}\left(\mathrm{PPh}_{3}\right)_{2}\right](2)$, which are apparently caused by a strong donating character of $\mathrm{PPh}_{3}$ ligand. Comparison of the electrochemical behavior of $\mathbf{1}$ and $\mathbf{2}$ showed that replacement of more electron rich $\mathrm{PPh}_{3}$ ligand in $\mathbf{2}$ by $\mathrm{CO}$ resulted in anodic shift of $E_{1 / 2}$ values of 1. Moreover, the first oxidation of $\mathbf{1}$ are quasi-reversible at the Pt- and GC-electrodes. Under the same CV conditions 2 undergoes an irreversible oxidation at $0.33 \mathrm{~V}$, this half wave oxidation potential value coincides with the oxidation potential value $\left(\mathrm{E}_{1 / 2}=0.33 \mathrm{~V}\right)$ of a mononuclear complex $\mathrm{Cp}(\mathrm{CO})_{2} \mathrm{Re}=\mathrm{C}=\mathrm{CHPh}$ [46]. This demonstrates that the one electron oxidation of 2 results in the mononuclear complex, which is clearly confirmed by the presence of two $v(\mathrm{CO})$ bands 1994 and $1920 \mathrm{~cm}^{-1}$, corresponding to $\mathrm{Cp}(\mathrm{CO})_{2} \mathrm{Re}=\mathrm{C}=\mathrm{CHPh}$ in the IR spectra of the solutions obtained after the controlled potential electrolysis of 2 , or by the isolation of $\mathrm{Cp}(\mathrm{CO})_{2} \mathrm{Re}=\mathrm{C}=\mathrm{CHPh}$ in quantitative yields after the reaction of 2 with $\left[\mathrm{Cp}_{2} \mathrm{Fe}\right]\left[\mathrm{BF}_{4}\right]$. In contrast to $\left[\mathrm{Cp}(\mathrm{CO})_{2} \operatorname{Re}(\mu-\right.$ $\left.\mathrm{C}=\mathrm{CHPh}) \mathrm{Pt}\left(\mathrm{PPh}_{3}\right)_{2}\right]$, no oxidation peaks of the mononuclear decomposition product was detected for complex 1 (Fig.2 - solid line), indicating the greater electrochemical stability of the last one relative to 2 .

${ }^{3}$ The ratio of cathodic to anodic peak currents $\mathrm{I}_{\mathrm{pc}} / \mathrm{I}_{\mathrm{pa}}=0.75\left(\mathrm{I}_{\mathrm{pc}}=14.01, \mathrm{I}_{\mathrm{pa}}=18.62\right), \Delta \mathrm{E}=\left|\mathrm{E}_{\mathrm{pa}}-\mathrm{E}_{\mathrm{pc}}\right|=136 \mathrm{mV}$ (Fig.2, peaks $\mathrm{A}_{1}, \mathrm{~A}_{1}{ }^{\prime}$ )

${ }^{4}$ The ratio of the anodic to cathodic peak currents $\mathrm{I}_{\mathrm{pa}} / \mathrm{I}_{\mathrm{pc}}=0.51\left(\mathrm{I}_{\mathrm{pa}}=14.30, \mathrm{I}_{\mathrm{pc}}=27.80\right), \Delta \mathrm{E}=\left|\mathrm{E}_{\mathrm{pc}}-\mathrm{E}_{\mathrm{pa}}\right|=89$ $\mathrm{mV}$ (Fig.2, peaks $\left.\mathrm{A}_{3}, \mathrm{~A}_{3}{ }^{\prime}\right)$ at GC-electrode and $\mathrm{I}_{\mathrm{pa}} / \mathrm{I}_{\mathrm{pc}}=0.76\left(\mathrm{I}_{\mathrm{pa}}=2.97, \mathrm{I}_{\mathrm{pc}}=3.91\right), \Delta \mathrm{E}=\left|\mathrm{E}_{\mathrm{pc}}-\mathrm{E}_{\mathrm{pa}}\right|=165 \mathrm{mV}$ at Ptelectrode 


\section{Conclusion}

Three synthetic methods were attempted to prepare the complex $\mathbf{1}$. The most convenient and high-yield approach to $\left[\mathrm{Cp}(\mathrm{CO})_{2} \operatorname{Re}(\mu-\mathrm{C}=\mathrm{CHPh}) \mathrm{Pt}\left(\mathrm{PPh}_{3}\right)(\mathrm{CO})\right](\mathbf{1})$ is based on the reactions of $\left[\mathrm{Cp}(\mathrm{CO})_{2} \mathrm{Re}(\mu-\mathrm{C}=\mathrm{CHPh}) \mathrm{Pt}\left(\mathrm{PPh}_{3}\right)_{2}\right]$ (2) with $\mathrm{Co}_{2}(\mathrm{CO})_{8}$ or $\mathrm{Rh}(\mathrm{acac})(\mathrm{CO})_{2}$. Remarkably, these reactions led to the selective substitution of the Pt-bound triphenylphosphine being in trans-position to vinylidene ligand with CO. Such reactivity of the initial complex 2 reflects the trans-influence of the vinylidene ligand.

The spectroscopic, structural and electrochemical features of 1 were described. Comparison of spectroscopic, XRD and electrochemical data of $\mathbf{1}$ with those of the previously synthesized binuclear vinylidene bridged complexes was carried out. The presence of the Pt-bound CO ligand slightly influences on the spectroscopic properties of the complex. The overall geometry of complex 1 is similar to those of the previously described $\mu$-vinylidene heterometallic complexes. At the same time, the geometric parameters and ${ }^{13} \mathrm{C}$ NMR data for the platinum-bound $\mathrm{CO}$ ligand of $\mathbf{1}$ differ from those of the another complexes containing the platinum-bound CO ligand. Such features of 1 arise from the trans-position of the $\mathrm{CO}$ group to the strong electron-withdrawing phenylvinylidene ligand. Significant changes are observed in electrochemical properties of $\mathbf{1}$, the electronwithdrawing carbonyl and vinylidene ligands makes the RePt core of $\mathbf{1}$ electron deficient and, consequently, resistant to oxidation in comparison to the previously described RePt $\mu$-vinylidene complexes.

\section{Acknowledgements}

This work was financially supported by Krasnoyarsk Region Science and Technology Support Fund (the junior scientists project no. 3/15).

\section{References}

[1] F. Ungvary, Application of transition metals in hydroformylation. Annual survey covering the year 2000, Coord. Chem. Rev. 218 (2001) 1-41. doi:10.1016/S0010-8545(01)00356-3.

[2] V. Ritleng, M.J. Chetcuti, Hydrocarbyl Ligand Transformations on Heterobimetallic Complexes, Chem. Rev. 107 (2007) 797-858. doi:10.1021/cr940270y.

[3] N. Wheatley, P. Kalck, Structure and Reactivity of Early-Late Heterobimetallic Complexes, Chem. Rev. 99 (1999) 3379-3420. doi:10.1021/cr980325m.

[4] S. Sculfort, P. Braunstein, Intramolecular $\mathrm{d}^{10}-\mathrm{d}^{10}$ interactions in heterometallic clusters of the transition metals, Chem. Soc. Rev. 40 (2011) 2741-2760. doi:10.1039/c0cs00102c.

[5] J.M. Thomas, B.F.G. Johnson, R. Raja, G. Sankar, P.A. Midgley, High-Performance Nanocatalysts for Single-Step Hydrogenations, Acc. Chem. Res. 36 (2003) 20-30. doi:10.1021/ar990017q.

[6] J. Xiao, R.J. Puddephatt, Pt-Re clusters and bimetallic catalysts, Coord. Chem. Rev. 143 (1995) 457-500. doi:10.1016/0010-8545(94)07008-8.

[7] R.D. Adams, B. Captain, Hydrogen Activation by Unsaturated Mixed-Metal Cluster Complexes: New Directions, Angew. Chemie Int. Ed. 47 (2008) 252-257. doi:10.1002/anie.200702407.

[8] H. Werner, F.J.G. Alonso, H. Otto, K. Peters, H.G. Von Schnering, Vinylidene Transitionmetal complexes, VI. The rhodium compounds $\mathrm{C}_{5} \mathrm{H}_{5} \mathrm{Rh}(=\mathrm{C}=\mathrm{CHR}) \mathrm{P}^{\mathrm{i}} \mathrm{Pr}_{3}$ as building blocks for the synthesis of heterometallic di- and trinuclear vinylidene-bridged complexes, Chem. Ber. 121 (1988) 1565-1573. doi:10.1002/cber.19881210906.

[9] A.B. Antonova, Use of the $\mathrm{Mn}=\mathrm{C}=\mathrm{C}$ system in organometallic and organic synthesis, Coord. Chem. Rev. 251 (2007) 1521-1560. doi:10.1016/j.ccr.2006.12.014.

[10] H. Werner, J. Wolf, G. Müller, C. Krüger, Ambidentate Behavior of Mononuclear Vinylidenerhodium Complexes-Novel C-C Coupling of a Methyl to a Vinylidene Group, Angew. Chemie Int. Ed. English. 23 (1984) 431-432. doi:10.1002/anie.198404311.

[11] N.E. Kolobova, L.L. Ivanov, O.S. Zhvanko, G.G. Aleksandrov, Y.T. Struchkov, Reactions of manganese $\pi$-acetylenic, $\eta$-vinylidenic, and $\eta$-allenylidenic complexes with $\mathrm{Fe}_{2}(\mathrm{CO})_{9}$. Crystal and molecular structure of $\mathrm{Cp}(\mathrm{CO})_{2} \mathrm{Mn}\left(\mu_{2}-\mathrm{C}=\mathrm{CHCOOCH}_{3}\right) \mathrm{Fe}(\mathrm{CO})_{4}$, J. Organomet. Chem. 228 (1982) 265-272. doi:10.1016/S0022-328X(00)84327-2. 
[12] N.E. Kolobova, L.L. Ivanov, O.S. Zhvanko, A.S. Batsanov, Y.T. Struchkov, Preparation of heterometallic complexes with chelating $\mu_{2}$-carbomethoxyvinylidene ligands. X-ray crystal structures of $\mathrm{Cp}(\mathrm{CO})_{2} \mathrm{MnW}(\mathrm{CO})_{4}(\mu-\mathrm{C}=\mathrm{CHCOOMe}) \quad$ and $\quad\left[\mathrm{Cp}(\mathrm{CO})_{2} \mathrm{Mn}\left(\mu_{2-}\right.\right.$ $\mathrm{C}=\mathrm{CHCOOMe})]_{2} \mathrm{Mo}(\mathrm{CO})_{2}\left(\mathrm{Cp}=\eta^{5}-\mathrm{C}_{5} \mathrm{H}_{5}\right)$, J. Organomet. Chem. 279 (1985) 419-432. doi:10.1016/0022-328X(85)87040-6.

[13] H. Werner, F.J.G. Alonso, H. Otto, K. Peters, H.G. Von Schnering, Synthese und kristallstruktur von heterometallzweikernkomplexen mit vinyliden-brückenliganden, J. Organomet. Chem. 289 (1985) c5-c12. doi:10.1016/0022-328X(85)88044-X.

[14] M.I. Bruce, Organometallic chemistry of vinylidene and related unsaturated carbenes, Chem. Rev. 91 (1991) 197-257. doi:10.1021/cr00002a005.

[15] J.R. Berenguer, M. Bernechea, J. Forniés, E. Lalinde, J. Torroba, Facile single or double C-H bond activation on $\eta 2$-Platinum-Complexed acetylenes by interaction with [cis- $\mathrm{PtR}_{2} \mathrm{~S}_{2}$ ] and [cis-PtR $2(\mathrm{CO}) \mathrm{S}] \quad\left(\mathrm{R}=\mathrm{C}_{6} \mathrm{~F}_{5}, \quad \mathrm{~S}=\mathrm{Thf}\right)$, Organometallics. 24 (2005) 431-438. doi:10.1021/om049208+.

[16] I. Ara, J.R. Berenguer, J. Forniés, E. Lalinde, M. Tomás, Unusual Formation and Reactivity of a Diplatinum $\mu$-Phenylethenylidene Complex: Synthesis and Structures of cis,cis$\left[\left(\mathrm{PPh}_{3}\right)\left(\mathrm{C}_{6} \mathrm{~F}_{5}\right)_{2} \mathrm{Pt}\left(\mu-\eta^{1}: \eta^{3}-\mathrm{CHPhCCO}\right) \mathrm{Pt}\left(\mathrm{PPh}_{3}\right)_{2}\right]$ and cis,cis-[( $\left.\mathrm{PPh}_{3}\right)_{2} \mathrm{Pt}\left\{\mu-\eta^{2}(\mathrm{C}, \mathrm{S}): \eta^{1}(\mathrm{C})-\right.$ $\left.\left.\mathrm{C}(\mathrm{SPh})\left(\mathrm{CH}_{2} \mathrm{Ph}\right)\right\} \mathrm{Pt}\left(\mathrm{C}_{6} \mathrm{~F}_{5}\right)_{2}(\mathrm{CO})\right]$ Dinuclear Compounds, Organometallics. 15 (1996) 1014 1022. doi:10.1021/om950891x.

[17] M. Knorr, C. Strohmann, P. Braunstein, Reactivity of Silylated Dinuclear Iron-Platinum Acyl Complexes: Formation of $\mu$-Vinylidene Complexes and Crystal Structures of the Acyl Complex $\left[(\mathrm{OC})_{3}\left\{(\mathrm{MeO})_{3} \mathrm{Si}\right\} \mathrm{Fe}(\mu\right.$-dppm $\left.) \mathrm{Pt}\{\mathrm{C}(\mathrm{O}) \mathrm{Me}\}(\mathrm{t}-\mathrm{BuNC})\right]$ and the $\mu$-Vinylidene Complex $\left[(\mathrm{OC})_{3} \mathrm{Fe}\{\mu-\mathrm{C}=\mathrm{C}(\mathrm{H}) \mathrm{Ph}\}(\mu\right.$-dppm $) \mathrm{Pt}\left(\mathrm{PPh}_{3}\right)$, Organometallics. 15 (1996) $5653-$ 5663. doi:10.1021/om9602670.

[18] M.R. Awang, J.C. Jeffery, F.G.A. Stone, Chemistry of di- and tri-metal complexes with bridging carbene or carbyne ligands. Part 22. Synthesis and some reactions of [bis(diphenylphosphino)methane]pentacarbonyl- $\mu$-[methoxy(methyl)methylene]-

platinumtungsten and crystal structure of $\left[\mathrm{PtW}\left(\mu-\mathrm{C}=\mathrm{CH}_{2}\right)(\mathrm{P}\right.$, J. Chem. Soc., Dalt. Trans. (1983) 2091-2098. doi:10.1039/DT9830002091.

[19] M.J. Chetcuti, K. Marsden, I. Moore, F.G.A. Stone, P. Woodward, Complexes with Bridging Carbene or Carbyne Ligands. Part 12. Reactions of the Complexes $\left[\mathrm{PtW}\left(\mu-\mathrm{CC}_{6} \mathrm{H}_{4}-\mathrm{Me}-\right.\right.$ 4) $\left.(\mathrm{CO})_{2}\left(\mathrm{PR}_{3}\right)_{2}\left(\eta-\mathrm{C}_{5} \mathrm{H}_{5}\right)\right]$ with carbon monoxide. Crystal Structure of $\left[\mathrm{Pt}_{2} \mathrm{~W}\left(\mu_{3}-\mathrm{CC}_{6} \mathrm{H}_{4} \mathrm{Me}-\right.\right.$ 4) $\left.(\mathrm{CO})_{4}\left(\mathrm{PMePh}_{2}\right)_{2}\left(\eta^{5}-\mathrm{C}_{5} \mathrm{H}_{5}\right)\right]$, J. Chem. Soc., Dalt. Trans. (1982) 1749-1755. doi:10.1039/DT9820001749.

[20] T.P. Spaniol, F.G. A. Stone, Compounds with Platinum-molybdenum or -tungsten bonds derived from the alkylidyne metal complexes $\left[\mathrm{M}(\mathrm{CR})(\mathrm{CO})_{2}\left(\eta-\mathrm{C}_{5} \mathrm{H}_{5}\right)\right](\mathrm{M}=\mathrm{Mo}$ or $\mathrm{W} ; \mathrm{R}=$ $\mathrm{C}_{6} \mathrm{H}_{4} \mathrm{Me}-4$ or $\left.\mathrm{C}_{6} \mathrm{H}_{3} \mathrm{Me}_{2}-2,6\right)$, Polyhedron. 8 (1989) 2271-2281. doi:10.1016/S02775387(00)81254-1.

[21] M. Knorr, P. Braunstein, A. Tiripicchio, F. Ugozzoli, Novel CO-Induced Silyl Migration in Heterobimetallic Iron-Palladium Methyl Complexes Leading to $\mu$-Siloxycarbene Complexes. Crystal Structures of the Metallasiloxanes $\left[(\mathrm{OC})_{3} \mathrm{Fe}\left\{\mu-\mathrm{Si}\left(\mathrm{OSiMe}_{3}\right)_{2}\left(\mathrm{OSiMe}_{3}\right)\right\}(\mu-\right.$ dppm $) \mathrm{PdCl}]$ and $\left[(\mathrm{OC})_{3}\left\{\left(\mathrm{Me}_{3} \mathrm{SiO}\right)_{3} \mathrm{Si}\right\} \mathrm{Fe}(\mu-\mathrm{dppm}) \mathrm{Pt}\left(\eta^{3}-\mathrm{C}_{3} \mathrm{H}_{5}\right)\right.$, Organometallics. 14 (1995) 4910-4919. doi:10.1021/om00010a063.

[22] R.R. Willis, C.E. Shuchart, A. Wojcicki, A.L. Rheingold, B.S. Haggerty, Heterobinuclear and Heterotrinuclear Metal $\mu$-Allenyl Complexes Containing Platinum and One or Both of Iron and Ruthenium. Synthesis of Higher Nuclearity Metal Complexes from Mononuclear Metal $\eta^{1}$-Propargyls and $\eta^{1}$-Allenyls and from Binuclear Metal $\mu-\eta^{1}: \eta_{\alpha}^{2}, \beta$-Allenyls, Organometallics. 19 (2000) 3179-3191. doi:10.1021/om000205g.

[23] A.B. Antonova, S. V. Kovalenko, E.D. Korniyets, P. V. Petrovsky, A.A. Johansson, N.A. Deykhina, Chemistry of vinylidene complexes. V. The ligand substitution reactions at the platinum atom in complexes $\mathrm{Cp}(\mathrm{CO}) 2 \mathrm{MnPt}(\mu-\mathrm{C}=\mathrm{CHPh}) \mathrm{L} 2$, Inorganica Chim. Acta. 105 (1985) 153-163. doi:10.1016/S0020-1693(00)90555-3.

[24] M. Bergamo, T. Beringhelli, G. D’Alfonso, P. Mercandelli, M. Moret, A. Sironi, Solid state and solution structure of the hetero-dimetallic complexes $\left[\mathrm{Cp}(\mathrm{CO}){ }_{2} \operatorname{Re}\{\mu-\right.$ 
$\mathrm{C}(\mathrm{OMe})(\mathrm{Ph})\} \mathrm{Pt}(\mathrm{COD})]$ and $\left[\mathrm{Cp}(\mathrm{CO}){ }_{2} \operatorname{Re}\{\mu-\mathrm{CPh}\} \mathrm{Pt}(\mathrm{COD})\right]^{+}$, containing bridging carbene and carbyne ligands, Inorganica Chim. Acta. 300-302 (2000) 1022-1034. doi:10.1016/S0020-1693(00)00024-4.

[25] M. Berry, J.A.K. Howard, F.G.A. Stone, Chemistry of di- and tri-metal complexes with bridging carbene or carbyne ligands. Part 2. Formation of manganese-platinum, -palladium, and -nickel compounds, and the crystal structures of two forms of $\left[(\mathrm{OC})_{4} \mathrm{Mn}\{\mu-(1-\sigma, 1-2-\eta-\right.$ $\left.\left.\left.\mathrm{C}=\mathrm{CH}-\mathrm{CH}_{2}-\mathrm{CH}_{2}-\mathrm{O}\right)\right\} \mathrm{Pt}\left(\mathrm{PMe}_{3}\right)_{2}\right]$, J. Chem. Soc., Dalt. Trans. (1980) 1601-1608. doi:10.1039/DT9800001601.

[26] J.C. Jeffery, I. Moore, M. Murray, F.G.A. Stone, Chemistry of Di- and Tri-metal Complexes with Bridging Carbene or Carbyne Ligands. Part 11. Some Reactions of the Compound $\left[\mathrm{PtW}\left\{\mu-\mathrm{C}(\mathrm{OMe}) \mathrm{C}_{6} \mathrm{H}_{4} \mathrm{Me}-4\right\}(\mathrm{CO})_{5}\left(\eta-\mathrm{C}_{8} \mathrm{H}_{12}\right)\right]$ and the Crystal Structure of One Isomer of $\left[\mathrm{Pt}_{3}\left\{\mu-\mathrm{C}(\mathrm{OMe}) \mathrm{C}_{6} \mathrm{H}_{4} \mathrm{Me}-4\right\}_{3}(\mathrm{CO})_{3}\right]$, J. CHEM. SOC. Dalt. TRANS. (1982) 1741-1747.

[27] A.B. Antonova, O.S. Chudin, A.D. Vasiliev, N.I. Pavlenko, W.A. Sokolenko, A.I. Rubaylo, O. V. Semeikin, Chemistry of vinylidene complexes. XVIII. Synthesis and molecular structure of the novel trinuclear $\mu 3$-vinylidene complex $\mathrm{CpReFePt}\left(\mu_{3}-\mathrm{C}=\mathrm{CHPh}\right)(\mathrm{CO})_{6}\left(\mathrm{PPh}_{3}\right)$, J. Organomet. Chem. 694 (2009) 127-130. doi:10.1016/j.jorganchem.2008.08.037.

[28] M.J. Chetcuti, J.A.K. Howard, R.M. Mills, F.G.A. Stone, P. Woodward, Chemistry of Diand Tri-metal complexes with bridging carbene or carbyne ligands. Part 13. Synthesis of Platinumirontungsten Tri-metal compounds with nu3-tolylidyne groups; crystal structures of $\left[\mathrm{FePtW}\left(\mu_{3}-\mathrm{CR}\right)(\mathrm{CO})_{5}\left(\mathrm{PMePh}_{2}\right)_{2}\left(\eta-\mathrm{C}_{5} \mathrm{H}_{5}\right)\right]$ and $\left[\mathrm{FePtW}\left(\mu_{3}-\mathrm{CR}\right)(\mathrm{CO})_{6}\right.$, J. Chem. Soc., Dalt. Trans. (1982) 1757-1764. doi:10.1039/DT9820001757.

[29] D.A. Valyaev, O. V. Semeikin, M.G. Peterleitner, Y.A. Borisov, V.N. Khrustalev, A.M. Mazhuga, E. V. Kremer, N.A. Ustynyuk, Oxidative dehydrodimerization of rhenium vinylidene complex $\left(\eta^{5}-\mathrm{C}_{5} \mathrm{H}_{5}\right)(\mathrm{CO})_{2} \mathrm{Re}=\mathrm{C}=\mathrm{C}(\mathrm{H}) \mathrm{Ph}$ : two competitive routes of coupling of $\sigma$ phenylethynyl intermediate $\left[\left(\eta^{5}-\mathrm{C}_{5} \mathrm{H}_{5}\right)(\mathrm{CO})_{2} \mathrm{Re}-\mathrm{C} \equiv \mathrm{CPh}\right]^{\circ}$. X-ray structures of rhenium mononuclear $\left(\eta^{5}-\mathrm{C}_{5} \mathrm{H}_{5}\right)(\mathrm{CO})_{2} \mathrm{Re}=\mathrm{C}=\mathrm{C}(\mathrm{H}) \mathrm{Ph}$ and binuclear $\left[\left(\eta^{5}-\mathrm{C}_{5} \mathrm{H}_{5}\right)(\mathrm{CO})_{2} \mathrm{Re}\right]_{2}(\mu-$ $\mathrm{C}=\mathrm{C}(\mathrm{Ph}) \mathrm{C} \equiv \mathrm{CPh})$ vinylidene compounds, J. Organomet. Chem. 689 (2004) 3837-3846. doi:10.1016/j.jorganchem.2004.07.038.

[30] D.R. Coulson, L.C. Satek, S.O. Grim, Tetrakis(triphenylphosphine)palladium(0), in: Inorg. Synth. , Vol. 13, Academic press, New-York, 2007: pp. 121-124. doi:10.1002/9780470132449.ch23.

[31] R.B. King, Organometallic Syntheses, in: Organomet. Synth., Elsevier, New-York, 1986: p. ii. doi:10.1016/B978-0-444-42607-9.50001-2.

[32] Y.S. Varshavsky, T.G. Cherkasova, Method of synthesis of acetylacetonatodicarbonylrhodium (i), Zh. Neorg. Khim. 12 (1967) 1709.

[33] A.B. Antonova, V. V. Verpekin, O.S. Chudin, A.D. Vasiliev, N.I. Pavlenko, W.A. Sokolenko, A.I. Rubaylo, O. V. Semeikin, Chemistry of vinylidene complexes. XXI. Synthesis, spectroscopic and structural study of the RePt and MnPt $\mu$-vinylidene complexes, Inorganica Chim. Acta. 394 (2013) 328-336. doi:10.1016/j.ica.2012.06.038.

[34] O.S. Chudin, W.A. Sokolenko, V. V. Verpekin, N.I. Pavlenko, A.I. Rubaylo, A.B. Antonova, Synthesis, molecular construction and Chemical properties of new vinylidene complexes with the Re-M bonds (M = Cu, Fe), J. Sib. Fed. Univ. Chem. 4 (2011) 424-431.

[35] G.M. Sheldrick, SADABS.Version 2.01. Bruker AXS Inc. Madison, Wisconsin, USA, 2004.

[36] G.M. Sheldrick, A short history of SHELX, Acta Crystallogr. Sect. A Found. Crystallogr. 64 (2008) 112-122. doi:10.1107/S0108767307043930.

[37] O.A. Gansow, A.R. Burke, W.D. Vernon, A Carbon-13 and Proton Magnetic Resonance. Examination of Solute Structures, Equilibria, and Structural Interconversions in Some Dinuclear $\eta^{5}$-Dienylruthenium, -iron, and -nickel Carbonyls, J. Am. Chem. Soc. 98 (1976) 5817-5826. doi:10.1021/ja00435a013.

[38] J.M. Anna, J.T. King, K.J. Kubarych, Multiple Structures and Dynamics of $\left[\mathrm{CpRu}(\mathrm{CO})_{2}\right]_{2}$ and $\left[\mathrm{CpFe}(\mathrm{CO})_{2}\right]_{2}$ in Solution Revealed with Two-Dimensional Infrared Spectroscopy, Inorg. Chem. 50 (2011) 9273-9283. doi:10.1021/ic200466b.

[39] J.C. Jeffery, H. Razay, F.G.A. Stone, Synthesis of Platinum-Manganese and -Rhenium Complexes with Bridging Thiocarbonyl Ligands; Crystal Structure of $[\operatorname{MnPt}(\mu-$ 
$\mathrm{CS})(\mathrm{CO})_{2}\left(\mathrm{PMePh}_{2}\right)_{2}\left(\eta-\mathrm{C}^{5} \mathrm{H}^{5}\right)$, J. Chem. Soc., Dalt. Trans. (1982) 1733-1739. doi:10.1039/DT9820001733.

[40] V. V. Verpekin, A.A. Kondrasenko, O.S. Chudin, A.D. Vasiliev, G. V. Burmakina, N.I. Pavlenko, A.I. Rubaylo, Chemistry of vinylidene complexes. XXIII. Binuclear rheniumpalladium vinylidene bridged complexes, their reactions with diiron nonacarbonyl, $\mathrm{J}$. Organomet. Chem. 770 (2014) 42-50. doi:10.1016/j.jorganchem.2014.07.024.

[41] K.A. Mead, I. Moore, F.G.A. Stone, P. Woodward, Chemistry of Di- and Tri-metal Complexes with Bridging Carbene or Carbyne Ligands. Part 21. Reactivity of $\mu$-(Methoxy-ptolylmethylene) and $\mu$-(p-Tolylmethylidene) groups at a platinum-tungsten centre. X-ray Crystal Structure of $\left[\mathrm{PtW}\left\{\mu-\mathrm{C}(\mathrm{OMe}) \mathrm{C}_{6} \mathrm{H}_{4} \mathrm{Me}-4\right\}\left(\mu-\mathrm{Ph}_{2} \mathrm{PCH}_{2} \mathrm{PPh}_{2}\right)(\mathrm{CO})_{5}\right]$, J. Chem. Soc., Dalt. Trans. (1983) 2083-2090. doi:10.1039/DT9830002083.

[42] A.B. Antonova, S. V. Kovalenko, E.D. Petrovsky, G.R. Gulbis, A.A. Johansson, Chemistry of vinylidene complexes. III. Binuclear manganese-platinum complexes with bridging phenylvinylidene ligand, Inorganica Chim. Acta. 96 (1985) 1-7. doi:10.1016/S00201693(00)93729-0.

[43] B. Cordero, V. Gómez, A.E. Platero-Prats, M. Revés, J. Echeverría, E. Cremades, F. Barragán, S. Alvarez, Covalent radii revisited, Dalt. Trans. (2008) 2832. doi:10.1039/b801115j.

[44] R.D. Adams, B. Captain, E. Trufan, L. Zhu, Activation of Metal Hydride Complexes by Tritert -butylphosphine-Platinum and -Palladium Groups, J. Am. Chem. Soc. 129 (2007) 75457556. doi:10.1021/ja070617h.

[45] J.C. Jeffery, I. Moore, F.G.A. Stone, Chemistry of Di- and Tri-metal Complexes with Bridging Carbene or Carbyne Ligands. Part 26. Reactions of the Compounds [PtW $\left\{\mu-\sigma: \eta^{3}-\right.$ $\left.\left.\mathrm{CH}\left(\mathrm{C}_{6} \mathrm{H}_{4} \mathrm{Me}-4\right)\right\}(\mathrm{CO})_{2}\left(\mathrm{PR}_{3}\right)_{2}\left(\eta-\mathrm{C}_{5} \mathrm{H}_{5}\right)\right]\left[\mathrm{BF}_{4}\right]\left(\mathrm{PR}_{3}=\mathrm{PMe}_{3}, \mathrm{PMe}_{2} \mathrm{Ph}, \mathrm{PMePh}_{2}\right)$ and $[\mathrm{PtW}\{\mu-$ $\left.\left.\sigma: \eta^{3}-\mathrm{C}(\mathrm{Me}) \mathrm{C}_{6} \mathrm{H}_{4} \mathrm{Me}-4\right\}(\mathrm{CO})_{2}\left(\mathrm{PMe}_{3}\right)_{2}\left(\eta-\mathrm{C}_{5} \mathrm{H}_{5}\right)\right]\left[\mathrm{SO}_{3} \mathrm{CF}_{3}\right]$ with Nueleophiles; X-Ray Crystal Structure of $\left[\mathrm{PtW}(\mu-\mathrm{H})-\left\{\mu-\mathrm{CH}\left(\mathrm{C}_{6} \mathrm{H}_{4} \mathrm{Me}-4\right)\right\}(\mathrm{CO})_{2}\left(\mathrm{PMe}_{3}\right)_{2}\left(\eta-\mathrm{C}_{5} \mathrm{H}_{5}\right)\right]$, J. Chem. Soc., Dalt. Trans. (1984) 1571-1580. doi:10.1039/DT9840001571.

[46] G. V. Burmakina, V. V. Verpekin, O.S. Chudin, D. V. Zimonin, N.I. Pavlenko, A.B. Antonova, A.I. Rubaylo, Electrochemical study of new binuclear heterometallic vinylidene complexes with the Re-Pt bond, J. Sib. Fed. Univ. Chem. 1 (2013) 51-59. 